

\section{Assessment Units}

Eight of 11 downdip Paleogene AUs were quantitatively assessed. These conventional AUs generally stack stratigraphically, and nearly all extend eastward from the United States-Mexico international border and northward from about the State-Federal waters limit. Table 1 lists input data used to calculate undiscovered resources in the eight conventional AUs.

The Hackberry Slope Sandstones AU incorporates upper Oligocene sandstone reservoirs of the middle part of the Frio Hackberry trend of eastern Texas and southwestern Louisiana (fig. 2). AU reservoirs comprise strata within rotated slide blocks and fill sequences in rotational fault accommodation spaces in updip areas and canyon and fan deposits farther downdip. Northern, western, and eastern AU boundaries are the limit of sand deposits in the Hackberry play, defined by Cossey and Jacobs (1992), and thus the limit of historical Hackberry production. The southern AU boundary is coincident with the northern boundary of the Frio Formation Slope Sandstones AU described below.

The Anahuac Formation Slope Sandstones AU comprises reservoirs in the downdip portion of the upper Oligocene Anahuac Formation. Paleodepositional systems of the reservoirs are sparse, shelf-fed channel, fan, and sheet sand deposits with the possibility of carbonate turbidites in eastern Louisiana. The updip AU boundary is the Frio paleoshelf margin, as interpreted by Galloway (2008), where transgressive facies of the Anahuac onlap the shelf.

\begin{tabular}{|c|c|c|c|c|}
\hline \multicolumn{2}{|c|}{ System } & Series & \multicolumn{2}{|c|}{ Group or Formation } \\
\hline \multirow{8}{*}{ 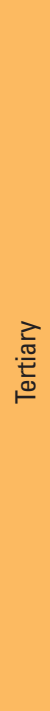 } & \multirow{8}{*}{ 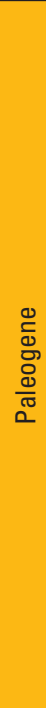 } & \multirow{3}{*}{ 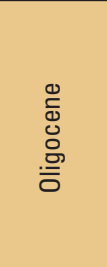 } & \multicolumn{2}{|c|}{ Anahuac Formation } \\
\hline & & & $\begin{array}{l}\text { Hackberry } \\
\text { trend }\end{array}$ & $\begin{array}{c}\text { Frio } \\
\text { Formation }\end{array}$ \\
\hline & & & \multicolumn{2}{|c|}{ Vicksburg Group } \\
\hline & & \multirow{3}{*}{ 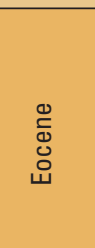 } & $\begin{array}{l}\text { Jackson } \\
\text { Group }\end{array}$ & $\begin{array}{c}\text { Moodys Branch } \\
\text { and Yazoo Formations }\end{array}$ \\
\hline & & & \multirow[t]{2}{*}{$\begin{array}{l}\text { Claiborne } \\
\text { Group }\end{array}$} & $\begin{array}{l}\text { Cockfield, Cook } \\
\text { Mountain, and } \\
\text { Yegua Formations } \\
\text { Sparta Sand }\end{array}$ \\
\hline & & & & Queen City Sand \\
\hline & & \multirow{2}{*}{ 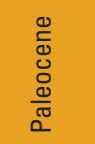 } & \multicolumn{2}{|c|}{ Wilcox Group } \\
\hline & & & \multicolumn{2}{|c|}{ Midway Group } \\
\hline
\end{tabular}

Figure 2. Generalized stratigraphic section of the northern Gulf of Mexico coastal plain downdip of the Paleogene shelf margins, modified from Schenk and Viger (1996).

Table 1. Key input data for eight conventional assessment units in the Tertiary slope sandstones of the downdip Paleogene formations, U.S. Gulf Coast region.

[AU, assessment unit; MMBO, million barrels of oil; BCFG, billion cubic feet of gas. Shading indicates not applicable]

\begin{tabular}{|c|c|c|c|c|c|c|c|c|}
\hline \multirow{2}{*}{$\begin{array}{c}\text { Assessment input data- } \\
\text { Conventional AUs }\end{array}$} & \multicolumn{4}{|c|}{ Hackberry Slope Sandstones AU } & \multicolumn{4}{|c|}{ Anahuac Formation Slope Sandstones AU } \\
\hline & Minimum & Median & Maximum & $\begin{array}{c}\text { Calculated } \\
\text { mean }\end{array}$ & Minimum & Median & Maximum & $\begin{array}{c}\text { Calculated } \\
\text { mean }\end{array}$ \\
\hline Number of oil fields & 1 & 3 & 6 & 3.1 & 1 & 6 & 30 & 6.8 \\
\hline Number of gas fields & 5 & 12 & 30 & 12.6 & 1 & 25 & 125 & 28.5 \\
\hline Size of oil fields (MMBO) & 0.5 & 0.7 & 20 & 1.1 & 0.5 & 1 & 100 & 2.5 \\
\hline Size of gas fields (BCFG) & 3 & 7 & 300 & 13.1 & 3 & 10 & 1,000 & 26.7 \\
\hline AU probability & 1.0 & & & & 1.0 & & & \\
\hline \multirow{2}{*}{$\begin{array}{l}\text { Assessment input data- } \\
\text { Conventional AUs }\end{array}$} & \multicolumn{4}{|c|}{ Frio Formation Slope Sandstones AU } & \multicolumn{4}{|c|}{ Vicksburg Group Slope Sandstones AU } \\
\hline & Minimum & Median & Maximum & $\begin{array}{c}\text { Calculated } \\
\text { mean }\end{array}$ & Minimum & Median & Maximum & $\begin{array}{c}\text { Calculated } \\
\text { mean }\end{array}$ \\
\hline Number of oil fields & 1 & 6 & 60 & 7.8 & 1 & 3 & 15 & 3.4 \\
\hline Number of gas fields & 2 & 50 & 220 & 55.9 & 3 & 60 & 250 & 66.6 \\
\hline Size of oil fields (MMBO) & 0.5 & 1 & 100 & 2.5 & 0.5 & 1 & 100 & 2.5 \\
\hline Size of gas fields (BCFG) & 3 & 10 & 1,500 & 31.9 & 3 & 8 & 1,500 & 27.5 \\
\hline AU probability & 1.0 & & & & 1.0 & & & \\
\hline \multirow{2}{*}{$\begin{array}{c}\text { Assessment input data- } \\
\text { Conventional AUs }\end{array}$} & \multicolumn{4}{|c|}{ Jackson Group Slope Sandstones AU } & \multicolumn{4}{|c|}{ Upper Claiborne Group Slope Sandstones AU } \\
\hline & Minimum & Median & Maximum & $\begin{array}{c}\text { Calculated } \\
\text { mean }\end{array}$ & Minimum & Median & Maximum & $\begin{array}{c}\text { Calculated } \\
\text { mean }\end{array}$ \\
\hline Number of oil fields & 1 & 3 & 15 & 3.4 & 1 & 7 & 50 & 8.5 \\
\hline Number of gas fields & 1 & 30 & 200 & 36.0 & 8 & 80 & 500 & 94.9 \\
\hline Size of oil fields (MMBO) & 0.5 & 1 & 100 & 2.5 & 0.5 & 1 & 100 & 2.5 \\
\hline Size of gas fields (BCFG) & 3 & 10 & 1,000 & 26.7 & 3 & 10 & 1,000 & 26.7 \\
\hline AU probability & 0.9 & & & & 1.0 & & & \\
\hline \multirow{2}{*}{$\begin{array}{c}\text { Assessment input data- } \\
\text { Conventional AUs }\end{array}$} & \multicolumn{4}{|c|}{ Lower Claiborne Group Slope Sandstones AU } & \multicolumn{4}{|c|}{ Wilcox Group Slope Sandstones AU } \\
\hline & Minimum & Median & Maximum & $\begin{array}{c}\text { Calculated } \\
\text { mean }\end{array}$ & Minimum & Median & Maximum & $\begin{array}{c}\text { Calculated } \\
\text { mean }\end{array}$ \\
\hline Number of oil fields & 1 & 3 & 20 & 3.6 & 1 & 5 & 30 & 5.9 \\
\hline Number of gas fields & 1 & 50 & 250 & 57.0 & 2 & 120 & 1,000 & 150.7 \\
\hline Size of oil fields (MMBO) & 0.5 & 1 & 100 & 2.5 & 0.5 & 1 & 100 & 2.5 \\
\hline Size of gas fields (BCFG) & 3 & 10 & 1,000 & 26.7 & 3 & 12 & 2,500 & 45.4 \\
\hline AU probability & 1.0 & & & & 1.0 & & & \\
\hline
\end{tabular}


The Frio Formation Slope Sandstones AU incorporates paleoslope sandstone reservoirs within lower to upper Oligocene Frio Formation strata. Paleodepositional systems of the reservoirs are both sand aprons in south Texas fed by the Norma and Norias Deltas and shelf-fed submarine channel and fan deposits throughout the AU. The updip AU boundary is the Frio shelf margin from Galloway (2008).

The Vicksburg Group Slope Sandstones AU consists of lower Oligocene Vicksburg Group sandstone reservoirs found downdip of the Vicksburg paleoshelf margin. Reservoirs are delta-fed aprons along the paleoshelf margin in Texas and sparsely distributed turbidite deposits throughout the AU, which therefore has a decreased probability. The updip AU boundary in south Texas is the Vicksburg shelf margin as defined by Coleman (1990), and the updip boundary in eastern Texas and southern Louisiana is the reinterpreted Vicksburg shelf margin and downdip limit of post-Vicksburg erosion.

The Jackson Group Slope Sandstones AU reservoirs comprise downdip equivalents of the upper Eocene and lower Oligocene Moodys Branch and Yazoo Formations. With a major paleodeposition center located downdip of the Rio Grande embayment, the AU only extends eastward to a facies change to primarily clay in the vicinity of the Texas-Louisiana State line. The Jackson paleoshelf margin from Galloway (2008) defines the northern AU limit.

The Upper Claiborne Group Slope Sandstones AU comprises downdip reservoirs of the middle Eocene Cockfield, Cook Mountain, and Yegua Formations and Sparta Sand (fig. 2). Paleodepositional systems included progradational shelf-fed and delta-fed aprons. The Yegua paleoshelf margin from Galloway (2008) defines the northern AU limit.

The Lower Claiborne Group Slope Sandstones AU comprises downdip reservoirs of the middle Eocene Queen City Sand. Sands of the Queen City were likely transported from the south Texas Rio
Grande embayment to the paleoshelf edge and beyond, though they are not interpreted to extend east past the Texas-Louisiana State line. The Queen City paleoshelf margin from Galloway (2008) defined the northern AU limit.

The Wilcox Group Slope Sandstones AU comprises paleoslope sandstone reservoirs of the Paleocene-Eocene Wilcox Group strata. Paleodepositional systems of the reservoir strata are sandy deltafed aprons and shelf-fed aprons in onshore Texas and Louisiana (McDonnell and others, 2008). The upper Wilcox Group shelf margin from Galloway (2008) defined the northern AU limit.

The continuous AUs reflect the extent of potentially selfsourcing shale oil and (or) gas resources. The Lower Claiborne Group Continuous AU, the Wilcox Group Continuous AU, and the Midway Group Continuous AU were defined where there is evidence of organic-rich, marine kerogen-rich mudstones in the oil-window or higher thermal maturity zone. There is no known development of continuous resources in this TPS from these three groups, and the source rock potential of these formations is not well known. Therefore, these three AUs were not quantitatively assessed.

\section{Undiscovered Resources Summary}

The USGS assessed undiscovered, technically recoverable resources for eight conventional oil and gas AUs in the downdip Paleogene formations (table 2). The estimated mean totals are 100 million barrels of oil (MMBO) with an F95-F5 range from 13 to $310 \mathrm{MMBO} ; 16,500$ billion cubic feet of gas (BCFG), or 16.5 trillion cubic feet of gas, with an F95-F5 range from 4,033 to 38,851 BCFG; and 409 million barrels of natural gas liquids (MMBNGL) with an F95-F5 range from 91 to 1,001 MMBNGL.

Table 2. Results for eight conventional assessment units in the Tertiary slope sandstones of the downdip Paleogene formations, U.S. Gulf Coast region.

[MMBO, million barrels of oil; BCFG, billion cubic feet of gas; NGL, natural gas liquids; MMBNGL, million barrels of natural gas liquids. Results shown are fully risked estimates. For gas accumulations, all liquids are included in the NGL category. F95 represents a 95-percent chance of at least the amount tabulated; other fractiles are defined similarly. Fractiles are additive under the assumption of perfect positive correlation. Shading indicates not applicable]

\begin{tabular}{|c|c|c|c|c|c|c|c|c|c|c|c|c|c|c|}
\hline \multirow{3}{*}{$\begin{array}{l}\text { Total petroleum system and } \\
\text { assessment units (AUs) }\end{array}$} & \multirow{3}{*}{$\begin{array}{c}\text { AU } \\
\text { prob- } \\
\text { ability }\end{array}$} & \multirow{3}{*}{$\begin{array}{c}\text { Accu- } \\
\text { mulation } \\
\text { type }\end{array}$} & \multicolumn{12}{|c|}{ Total undiscovered resources } \\
\hline & & & \multicolumn{4}{|c|}{ Oil (MMBO) } & \multicolumn{4}{|c|}{ Gas (BCFG) } & \multicolumn{4}{|c|}{ NGL (MMBNGL) } \\
\hline & & & F95 & F50 & F5 & Mean & F95 & F50 & F5 & Mean & F95 & F50 & F5 & Mean \\
\hline \multicolumn{15}{|c|}{ Upper Jurassic-Cretaceous-Tertiary Composite Total Petroleum System } \\
\hline \multirow{2}{*}{ Hackberry Slope Sandstones AU } & \multirow{2}{*}{1.0} & Oil & 1 & 3 & 7 & 3 & 3 & 8 & 25 & 10 & 0 & 0 & 1 & 0 \\
\hline & & Gas & & & & & 71 & 146 & 321 & 164 & 4 & 10 & 24 & 11 \\
\hline \multirow{2}{*}{ Anahuac Formation Slope Sandstones AU } & \multirow{2}{*}{1.0} & Oil & 3 & 12 & 50 & 17 & 3 & 16 & 85 & 30 & 0 & 1 & 3 & 1 \\
\hline & & Gas & & & & & 187 & 635 & 1,759 & 759 & 6 & 23 & 77 & 30 \\
\hline \multirow{2}{*}{ Frio Formation Slope Sandstones AU } & \multirow{2}{*}{1.0} & Oil & 2 & 12 & 62 & 19 & 2 & 17 & 104 & 30 & 0 & 1 & 5 & 2 \\
\hline & & Gas & & & & & 528 & 1,548 & 3,828 & 1,780 & 17 & 57 & 167 & 70 \\
\hline \multirow{2}{*}{ Vicksburg Group Slope Sandstones AU } & \multirow{2}{*}{1.0} & Oil & 1 & 5 & 27 & 8 & 1 & 7 & 45 & 13 & 0 & 0 & 2 & 1 \\
\hline & & Gas & & & & & 571 & 1,609 & 3,853 & 1,833 & 19 & 59 & 169 & 72 \\
\hline \multirow{2}{*}{ Jackson Group Slope Sandstones AU } & \multirow{2}{*}{0.9} & Oil & 0 & 4 & 26 & 8 & 0 & 10 & 70 & 20 & 0 & 1 & 3 & 1 \\
\hline & & Gas & & & & & 0 & 695 & 2,291 & 866 & 0 & 15 & 51 & 19 \\
\hline \multirow{2}{*}{$\begin{array}{l}\text { Upper Claiborne Group Slope } \\
\text { Sandstones AU }\end{array}$} & \multirow{2}{*}{1.0} & Oil & 3 & 14 & 64 & 21 & 7 & 35 & 170 & 55 & 0 & 2 & 9 & 3 \\
\hline & & Gas & & & & & 739 & 2,121 & 5,664 & 2,517 & 16 & 47 & 126 & 56 \\
\hline \multirow{2}{*}{$\begin{array}{l}\text { Lower Claiborne Group Slope } \\
\text { Sandstones AU }\end{array}$} & \multirow{2}{*}{1.0} & Oil & 1 & 5 & 29 & 9 & 2 & 12 & 79 & 23 & 0 & 1 & 4 & 1 \\
\hline & & Gas & & & & & 443 & 1,313 & 3,307 & 1,521 & 9 & 29 & 75 & 34 \\
\hline \multirow{2}{*}{ Wilcox Group Slope Sandstones AU } & \multirow{2}{*}{1.0} & Oil & 2 & 10 & 45 & 15 & 5 & 23 & 120 & 38 & 0 & 1 & 4 & 1 \\
\hline & & Gas & & & & & 1,471 & 5,420 & 17,130 & 6,841 & 20 & 82 & 281 & 107 \\
\hline Total undiscovered conventional resources & & & 13 & 65 & 310 & 100 & 4,033 & 13,615 & 38,851 & 16,500 & 91 & 329 & 1,001 & 409 \\
\hline
\end{tabular}




\section{References Cited}

Coleman, J.M.C., 1990, Depositional systems and tectonic/ eustatic history of the Oligocene Vicksburg episode of the northern Gulf Coast: University of Texas at Austin, Ph.D. dissertation, $722 \mathrm{p}$.

Cossey, S.P.J., and Jacobs, R.E., 1992, Oligocene Hackberry formation of southwest Louisiana-Sequence stratigraphy, sedimentology, and hydrocarbon potential: American Association of Petroleum Geologists Bulletin, v. 76, no. 5, p. 589-606.

Dubiel, R.F., Pitman, J.K., Pearson, O.N., Warwick, P.D., Karlsen, A.W., Coleman, J.L., Hackley, P.C., Hayba, D.O., Swanson, S.M., Charpentier, R.R., Cook, T.A., Klett, T.R., Pollastro, R.M., and Schenk, C.J., 2007, Assessment of undiscovered oil and gas resources in Tertiary strata of the Gulf Coast, 2007: U.S. Geological Survey Fact Sheet 2007-3066, 4 p. [Also available at https://pubs.usgs.gov/fs/2007/3066/.]

Galloway, W.E., 2008, Depositional evolution of the Gulf of Mexico sedimentary basin, chap. 15 of Miall, A.D., ed., The sedimentary basins of the United States and Canada, volume 5: The Netherlands, Elsevier, Sedimentary Basins of the World, p. 505-549.

Hood, K.C., Wenger, L.M., Gross, O.P., and Harrison, S.C., 2002, Hydrocarbon systems analysis of the northern Gulf of Mexico-Delineation of hydrocarbon migration pathways using seeps and seismic imaging, in Schumacher, D., and LeShack, L.A., eds., Surface exploration case historiesApplications of geochemistry, magnetics, and remote sensing: American Association of Petroleum Geologists, Studies in Geology No. 48, and Society of Economic Geologists, Geophysical References Series No. 11, p. 25-40.
McDonnell, A., Loucks, R.G., and Galloway, W.E., 2008, Paleocene to Eocene deep-water slope canyons, western Gulf of Mexico-Further insights for the provenance of deepwater offshore Wilcox Group plays: American Association of Petroleum Geologists Bulletin, v. 92, no. 9, p. 1169-1189.

Salvador, A., ed., 1991, The Gulf of Mexico Basin: Boulder, Colo., Geological Society of America, Decade of North American Geology, v. J, 568 p.

Schenk, C.J., and Viger, R.J., 1996, Western Gulf Province (047), in Gautier, D.L., Dolton, G.L., Takahashi, K.I., and Varnes, K.I., eds., 1995 national assessment of United States oil and gas resources-Results, methodology, and supporting data [release 2]: U.S. Geological Survey Digital Data Series DDS-30, 44 p. [Also available at https://certmapper.cr.usgs.gov/data/noga95/ prov47/text/prov47.pdf.]

Sømme, T.O., Helland-Hansen, W., Martinsen, O.J., and Thurmond, J.B., 2009, Relationships between morphological and sedimentological parameters in source-to-sink systemsA basis for predicting semi-quantitative characteristics in subsurface systems: Basin Research, v. 21, no. 4, p. 361-387.

Warwick, P.D., Coleman, J.L., Hackley, P.C., Hayba, D.O., Karlsen, A.W., Rowan, E.L., and Swanson, S.M., 2007, USGS assessment of undiscovered oil and gas resources in Paleogene strata of the U.S. Gulf of Mexico Coastal Plain and State waters, in Kennan, L., Pindell, J., and Rosen, N.C., The Paleogene of the Gulf of Mexico and Caribbean Basins-Processes, events, and petroleum systems: 27th Annual Gulf Coast Section Society for Sedimentary Geology (GCSSEPM) Bob F. Perkins Research Conference, December 2-5, 2007, Houston, Texas [Proceedings], CD-ROM, p. 2-44.

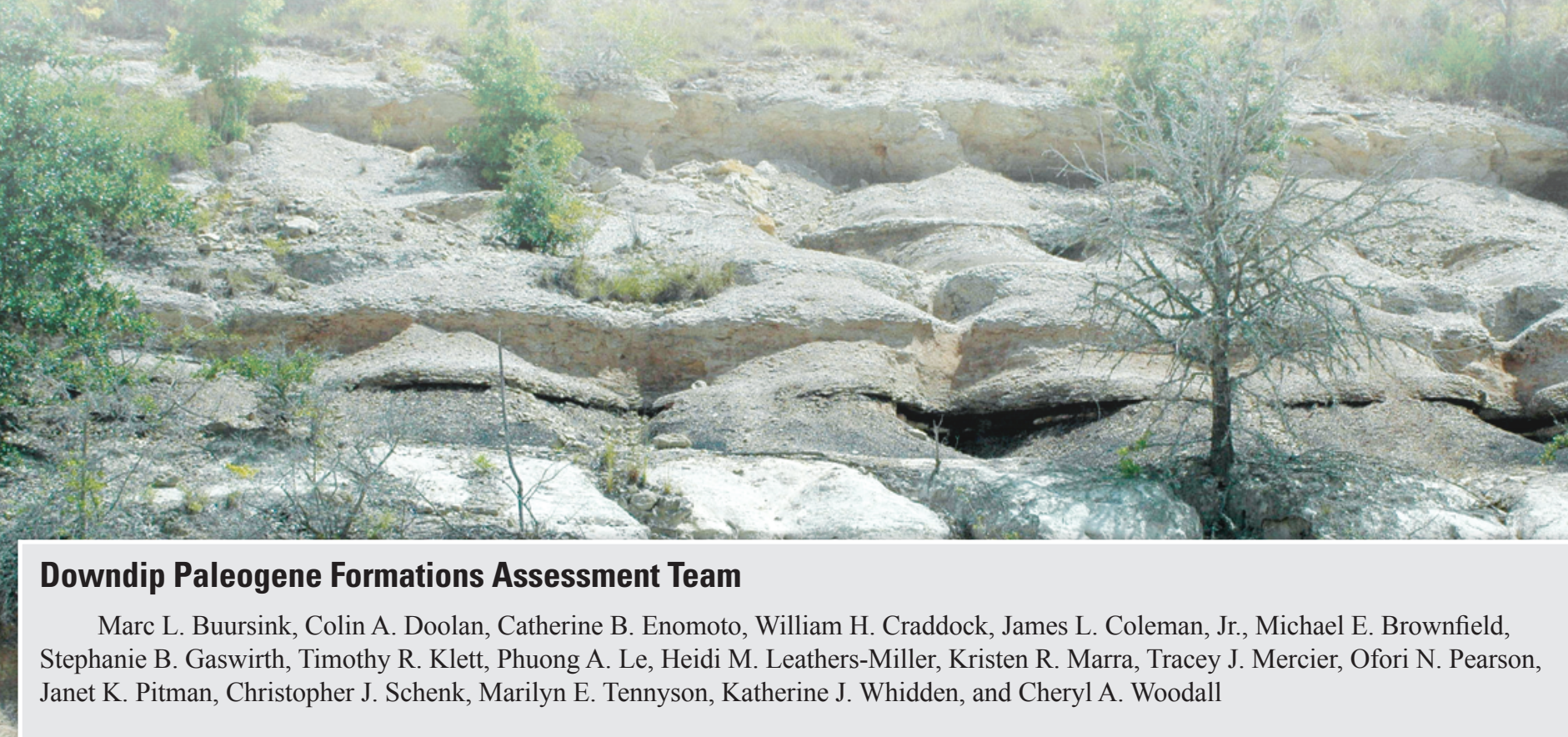

\section{For More Information}

Assessment results are also available at the USGS Energy Resources Program website at https://energy.usgs.gov.

Photograph of an outcropping of Eocene Jackson Group rocks at Lake Somerville, Texas. These sandstones may be considered general shallow-water equivalents to the slope sandstones investigated in this Paleogene assessment. Photograph by James L. Coleman, Jr., is also used as banner image. 